\title{
Evaluation of Microfine Palm Oil Fuel Ash (POFA) as Cement Partial Replacement Material for Mitigation of Chloride Attack
}

\author{
Raudhah Ahmadi $^{1}$, Mohd Syukry Saiful ${ }^{1}$, Dzul Fahmi Zawawi ${ }^{1}$, Shahrul Zaman Abdul Rahman ${ }^{1}$, Idawati Ismail ${ }^{1}$, \\ Mohamad Abdul Mannan ${ }^{1}$, Ana Sakura Zainal Abidin ${ }^{2}$ and Fadzli Mohamed Nazri ${ }^{3}$. \\ ${ }^{1}$ Department of Civil Engineering, Faculty of Engineering, Universiti Malaysia Sarawak \\ ${ }^{2}$ Department of Mechanical and Manufacturing Engineering, Faculty of Engineering, Universiti Malaysia Sarawak \\ ${ }^{3}$ School of Civil Engineering, Engineering Campus, Universiti Sains Malaysia \\ *Corresponding author E-mail: araudhah@unimas.my
}

\begin{abstract}
This paper investigates the effect of microfine palm oil fuel ash (POFA) as cement replacement material for mitigation of chloride attack in concrete. The raw POFA obtained from a local palm oil mill is initially grinded using Los Angeles abrasion machine, and then sieved using $150 \mu \mathrm{m}$ sieve before it is burned in a furnace at $500^{\circ} \mathrm{C}$. The burned POFA is then grinded using electric powder grinder to obtain the targeted microfine size ranging between 1-10 $\mu \mathrm{m}$. Treated microfine POFA is used in the production of concrete samples for experimental tests; compressive strength test, sorptivity test and chloride penetration test to determine its physical properties and the chloride resistance parameter for the mitigation of chloride attack in concrete. Results showed that $20 \%$ of microfine POFA replacement in concrete gives the highest compressive strength at $56^{\text {th }}$ day and reduces the rate of absorption of water and chloride penetration.
\end{abstract}

Keywords: Cement replacement; Chloride attack; Microfine POFA.

\section{Introduction}

Malaysia has been facing major problem in disposing palm oil fuel ash (POFA) since many years ago. Furthermore, Malaysia has become the second largest palm oil producer since 2010, as the production of palm oil is almost 18.6 million metric tons $[1,8]$. Hence, to make benefits from it as well as conserving the environment, POFA can be applied as cement replacement material especially in the production of high strength and high durability concrete. A study carried out by [2] discovered that the optimum POFA replacement in concrete is at $30 \%$ by weight of the binder, which increases the compressive strength of concrete compared to the usage of purely Ordinary Portland Cement. The outcome of this study also has come to an agreement with [3] that proved the inclusion of $40 \%$ microfine POFA could increase the workability and viscosity of the ultra-high strength concrete. A study by [1] also found that concrete made with $10 \mu \mathrm{m}$ POFA as partial cement replacement material has higher resistance to acid attack than concrete made with $45 \mu \mathrm{m}$ POFA. It is deduced that the durability of concrete made with finer size of POFA particles as partial cement replacement is much higher than when using larger particle size of POFA. Hence, this research focuses on investigating the effect of microfine sized POFA ranging from 1-10 $\mu \mathrm{m}$ as cement replacement material that could mitigate chloride attack.

\section{Materials and Experimental Procedures}

This research mainly focused on the utilization of microfine POFA as cement replacement in the concrete mix on the aspects related to compressive strength, rate of absorption (sorptivity) and resistance on chloride attack in concrete using Nordtest (NT Build 492) [4].

\subsection{Material}

The raw POFA used in this research is collected from a local palm oil mill (Bau, Lundu Palm Oil Mill, Sarawak, Malaysia) and is treated before grinded to produce particle sizes ranging from 1-10 $\mu \mathrm{m}[5,6]$.

\subsection{Mix Design}

The acceptable particle size of processed POFA, which is ranging between $1-10 \mu \mathrm{m}$ is then being applied into the production of concrete cubes with the dimension of $100 \mathrm{~mm}^{3}$ and concrete cylinders (diameter of $100 \mathrm{~mm}$ and height of $200 \mathrm{~mm}$ ). A total number of 18 concrete cubes and 24 concrete cylinders are produced in order to perform the tests to determine its engineering properties. The outcome from the mix design is tabulated in Table 1. Samples are fully submerged in tap water under normal room temperature, $27^{\circ} \mathrm{C}$ after de-moulding for 7,28 and 56 days.

\begin{tabular}{lccc}
\multicolumn{4}{c}{ Table 1: Mix design } \\
\cline { 2 - 4 } Materials & \multicolumn{3}{c}{ Quantity $\left(\mathrm{per} \mathrm{kg} / \mathrm{m}^{3}\right)$} \\
\hline Water/Cement & 0.47 & $10 \%$ POFA & $20 \%$ POFA \\
Ratio & 480 & 0.47 & 0.47 \\
Cement Content & 0 & 432 & 384 \\
POFA Content & 225 & 48 & 96 \\
Water Content & 1185 & 225 & 225 \\
Coarse Aggregate & 460 & 1185 & 1185 \\
Fine Aggregate & & 460 & 460 \\
\hline
\end{tabular}

